Uşak Üniversitesi Sosyal Bilimler Dergisi

$2014,7 / 3$

\title{
Kurumsal Yönetim Derecelendirme Notu ile Piyasa Değeri Arasındaki İlişki: BIST XKURY Şirketleri Üzerine Bir Araştırma*
}

Veysel KULA*

Ender BAYKUT ${ }^{* * * *}$

\section{Özet}

Kurumsal yönetim uygulamaları paydaşlar arasındaki çıkar çatışmalarını engellemeye yönelik uygulamalar bütünü olarak yatırımcılar açısından şirketin cazibesini arttıran bir unsurdur. Türkiye'de kurumsal yönetim uygulamaları 2000'li yıllar sonrası mevzuat düzenlemesine tabi olmuş olup bu kapsamda 2007 yılı itibariyle Borsa İstanbul'da Kurumsal Yönetim Endeksi oluşturulmuştur. Mevcut çalışmada söz konusu endekste yer alan 47 şirketin, 2013 yılının üçüncü çeyrek verileri kullanarak, kurumsal yönetim derecelendirme notu ile piyasa değeri arasındaki ilişki yatay-kesit regresyon yönetimi ile araştırılmıştır. Analizde kurumsal yönetim derecelendirme notları yanı sıra bağımsız değişken olarak kârlılık, özsermaye büyüklüğü ve sektörel ayrım da dâhil edilmiştir. Analiz sonucunda kurumsal yönetim derecelendirme notları, kârlılık ve sektörel ayrım ile şirketlerin piyasa değerleri arasında pozitif anlamlı ilişki; özsermaye büyüklüğü ve piyasa değeri arasında ise negatif anlamlı bir sonuç elde edilmiştir. Elde edilen sonuçlar, ileri kurumsal yönetim uygulamalarının; yüksek piyasa değeri ve daha iyi finansal performans getirdiği hipotezini desteklemektedir.

Anahtar Kelimeler: Kurumsal Yönetim, Kurumsal Yönetim Endeksi, Kurumsal Yönetim Derecelendirme Notu, BIST XKURY, Piyasa Değeri.

\section{Relationship between Corporate Governance Ratings and Firm Market Value: An Analysis of BIST XKURY Companies}

\section{Abstract}

As a body of arrangements to deal with the conflicts of interests among stakeholders, corporate governance measures increase the

\footnotetext{
* Bu çalışmada TÜBA desteğinden yararlanılmıştır.

** Prof. Dr., Afyon Kocatepe Üniversitesi, İ.İ.B.F., Uluslararası Ticaret ve Finansman Bölümü

*** Arş. Grv., Afyon Kocatepe Üniversitesi, İ.İ.B.F., İngilizce İşletme Bölümü
} 
attractiveness of companies to investors. Newly subjected to regulation in Turkey only since 2000s, Corporate Governance Index was established in Borsa Istanbul in 2007. By cross-section regression analysis of 2013 thirdquarter data of 47 companies in the index, the study aims at investigating the effect of corporate governance ratings on market values of companies. Profitability performance, total equity and sectoral breakdown also included to analysis as an independent variable. The results of the analysis reveal that corporate governance ratings, profitability performance and sectoral breakdown affect firm market value in a statistically significant positive way while total equity affect firm market value in statistically significant negative way. The findings support the hypohesis that better corporate governance applications is associated with higher value and better financial performances.

Key Words: Corporate Governance, Corporate Governance Index, Corporate Governance Ratings, BIST XKURY, Market Value.

\section{Giriş}

Modern finans yaklaşımı, şirketlerin temel amacını ortaklarının varlığının maksimize edilmesi olarak kabul etmekle birlikte bu amaç sadece şirket ortaklarının çabaları ile gerçekleştirilememektedir. Söz konusu amaca ulaşabilme noktasında ortakların yanı sıra çalışanlar, kreditörler, tedarikçiler ve müssteriler gibi diğer paydaşların da katkı sağlaması gerekmektedir. Paydaşların her birisinin ise kendilerine mahsus önceledikleri farklı amaçları, çıkarları vardır. Bu farklı çıkarlar arasındaki çatışmayı hedef alıp şirketin amacını gerçekleştirilmesine katkı sağlayan en önemli tedbir ve faaliyetler bütünü kurumsal yönetim uygulamaları olarak bilinmektedir.

Kurumsal yönetim ile ilgili en yaygınca bilinen tanım Shleifer ve Vishny (1997:737) tarafından yapılmıştır. Bu tanıma göre, kurumsal yönetim; "şirketlere fon sağlayan yatırımcıların, yatırımlarını geri alabilmeleri için şirketlerin uyması gereken kurallar ve yöntemler" şeklinde ifade edilmiştir. OECD (1999:2) ise “OECD Kurumsal Yönetim İlkeleri”nde kurumsal yönetimi; "yönetim kurulu, hissedarlar ve paydaşlar arasındaki ilişkileri düzenleyen sistemler topluluğu" olarak tanımlamıştır. Genel olarak değerlendirildiğinde kurumsal yönetimin dar ve geniş kapsamlı olmak üzere iki şekilde tanım grubu olduğu görülmektedir. Dar kapsamdaki tanımlamada odaklanma şirket hissedarları üzerinedir. Bu kapsamda, kurumsal yönetim şirket yönetimi ile hissedarlar ve paydaşlar arasındaki 
ilişkileri düzenleyen, hissedarların haklarının şirket tarafından tanınmasına olanak sağlayıp, bu haklarının etkin şekilde kullandırılmasına yardımcı olan ve uzun vadede hissedarlarına ekonomik değer yaratmaya imkân sağlayan her türlü kanun, yönetmelik, kod ve uygulamalardır (Aktan, 2006:2; Aysan, 2007:18; Güçlü, 2010:21; TKYD, 2011:13; TÜSİAD, 2002:9). Geniş kapsamlı yaklaşımda ise kurumsal yönetim; modern yaşamda bir amaca ulaşmak için şirket yönetimi ile toplumun ilişkilerini düzenleyen ve iyi şirket yönetimi için gerekli resmi ve resmi olmayan kurallar bütünü olarak tanımlanabilmektedir (Aktan, 2006:5; TÜSİAD, 2002:9; Aysan, 2007:18).

90 'l y yllarda yaşanan finansal skandallardan sonra kurumsal yönetim ile ilgili evrensel ilkelerin geliştirilmesi ihtiyacı ortaya çıkmıştır. 1999 yılında OECD Kurumsal yönetim ile ilgili olarak “OECD Kurumsal Yönetim İlkeleri" ismiyle konu ile ilgili uluslararası ölçeği kapsayan ilk raporu yayımlamıştır. Bu raporu referans alan OECD'ye üye ülkeler, daha sonra kurumsal yönetim ilkelerinin uygulamasına yönelik mevzuat geliştirme çabalarına girişmişlerdir. Eylül 1999'da Türkiye Bankalar Birliği bünyesinde faaliyet gösteren Basel Bankacılık Gözetim Komitesi tarafından OECD ilkeleri esas alarak hazırlanan "Bankalarda Kurumsal Yönetim" isimli rapor (TBB, 1999:3) Türkiye'de kurumsal yönetim alanındaki ilk düzenleme girişimlerindendir. Bu çalışmayı, 2002 yılında TÜSİAD tarafından hazırlanan "Kurumsal Yönetim: En İyi Uygulama Kodu" isimli rapor izlemiş̧ir. Denetleyici ve düzenleyici otorite olan SPK'nın kurumsal yönetim ile ilgili ilk çalışması ise 2003 yılında hazırlanıp kamuoyuna sunulmuştur. "SPK Kurumsal Yönetim İlkeleri" ismiyle yayımlanan bu çalışma "uygula ya da açıkla " prensibine dayanmaktadır. Uluslararası gelişmeler karşısında, bu ilkeler 2005 ve 2010 yıllarında güncelleştirilip kamuoyuna sunulmuştur. "Uygula ya da Açıkla" prensibinin gereği olarak kurumsal yönetim uyum beyanı ile ilgili raporlarının zorunluluk haline getirilmesi, kurumsal yönetim ile ilgili bir diğer önemli gelişme olmuştur.

Kurumsal yönetim alanındaki bu gelişmeler Ağustos 2007'de Kurumsal Yönetim Endeksi'nin (XKURY) oluşturulması ile devam etmiştir. Borsa İstanbul (BİST) Kurumsal Yönetim Endeksi'nin (XKURY) amac1, payları BİST pazarlarında (Gözaltı Pazarı ve C Listesi hariç) işlem gören ve kurumsal yönetim ilkelerine uyum notu 10 üzerinden en az 7 olan şirketlerin fiyat ve getiri performansının ölçülmesidir. Kurumsal Yönetim İlkelerine uyum notu, SPK tarafından belirlenmiş derecelendirme kuruluşları listesinde bulunan derecelendirme kuruluşlarınca, şirketin tüm kurumsal yönetim ilkelerine bir bütün olarak uyumuna ilişkin yapilan değerlendirme sonucunda verilmektedir (BİST, 2013). 31.08.2007 tarihinde kurumsal yönetim derecelendirme notu en az 7 olan şirket sayısının beşe 
ulaşması ile hesaplanmaya başlayan XKURY, Şubat 2014 itibariyle çeşitli sektörlerden 47 şirketin işlem gördüğü bir endeks haline gelmiştir.

$\mathrm{Bu}$ çalışma, BİST XKURY bünyesinde işlem gören 47 şirketin ulaşılabilir en son 2013 yılı üçüncü çeyrek verileri kullanarak kurumsal yönetim derecelendirme notlarının, şirketlerin piyasa değeri üzerine etkisini araştırmayı hedeflemiştir. Yatay-kesit regresyon analizi yönteminin kullanıldığı çalışmada ayrıca sektör farklılıklarının, net kârın ve özkaynak büyüklüğünün de şirket değeri üzerindeki etkisi de araştırılacaktır. Literatür incelemesinde, kurumsal yönetim endeksinde yer alan şirketlerin derecelendirme notlarının ve sektörel farklılıklarının, piyasa değerine olan etkisini, regresyon analizi ile ele alan herhangi bir çalışmaya rastlanmamıştır. $\mathrm{Bu}$ nedenle mevcut çalışmanın literatüre orijinal bir katkı sağlayacağı düşünülmektedir.

Çalışmanın takip eden bölümünde, kurumsal yönetim ile finansal performans arasındaki ilişkiyi ortaya koyan literatür araştırmasına yer verilmiştir. Çalışmanın üçüncü bölümünde veri ve metodoloji hakkında bilgi verilip analiz sonuçları sunulacaktır. Çalışma, bulgu yorumlarını içeren dördüncü bölüm ile sona ermektedir.

\section{Literatür Araştırması}

Sherman (2004:6) tarafından da ifade edildiği üzere, kurumsal yönetim uygulamaları ile şirketler kısa vadede yatırımcının güvenini kazanıp uzun vadede daha fazla getiri elde etmekte ve oluşan yatırımcı güveni sonucu sermaye maliyetini azaltabilmektedirler. Şirketlerin kurumsal yönetim ilkeleri çerçevesinde yönetilmelerinin şirket değerine olumlu katkısını ortaya koyan çok sayıda çalışma mevcuttur. Örneğin, Mc Kinsey araştırma şirketinin (2002) 2000 yılında yaptığ çalışmaya göre, yatırımcıların, kurumsal yönetim ilkelerini benimseyen ve uygulayan bir şirketin hisse senetlerine \%28 daha fazla fiyat ödemeye razı oldukları görülmüştür.

1990'1ı yıllarda 24 farklı kurumsal yönetim göstergesini kullanarak Amerika'da 1500 şirketten oluşan bir kurumsal yönetim endeksi oluşturan Gompers vd. (2003:144-145), bu endeksteki şirketlerin değeri ve endeksin getiriler üzerine performanslarını incelemişlerdir. Bu çalışmanın sonuçlarına göre; kurumsal yönetim puanı düşük olan hisse senetlerini satıp yüksek olan hisse senetlerini satın alan bir yatırımcı daha fazla getiri elde edebilmektedir.

Morey vd. (2009) 5 yıl boyunca gelişmekte olan 21 ülkeden çeşitli şirketlerin kurumsal yönetim derecelendirme notları ile piyasa değeri 
arasındaki ilişkiyi inceledikleri çalışmalarında, kurumsal yönetim derecelendirme notu yüksek olan şirketlerin piyasa değerinin de yüksek oldukları sonucuna ulaştıkları görülmüştür.

2001 yllında Kore Borsasında işlem gören 515 şirket üzerine yaptıkları çalışmada Black vd. (2003) kurumsal yönetim yapısı ve kurumsal yönetim derecelendirme notlarının şirketlerin piyasa değeri üzerindeki etkisini araştırmışlardır. Çalışmanın sonuçlarına göre, kurumsal yönetim derecelendirme notları ile piyasa değeri arasında anlamlı bir pozitif ilişki tespit edilmiştir.

Ficici ve Aybar (2012) ise gelişmekte olan 9 ülkeden 55 şirket üzerine yaptıkları çalışmada, kurumsal yönetim derecelendirme notu ve piyasa değeri arasındaki ilişkiyi incelenmişlerdir. Regresyon yöntemi kullanılarak yapılan analizin sonuçlarına göre, kurumsal yönetim derecelendirme notları ile şirketin piyasa değeri arasında pozitif bir ilişki tespit edilmiştir.

Sakarya (2011) ise çalışmasında, hisse senetleri BİST'de işlem gören ve 2009 yılında kurumsal yönetim derecelendirme notu alarak XKURY kapsamına alınan 11 şirketin derecelendirme notunun ilanı ile hisse senedi getirileri arasındaki ilişkiyi incelemiştir. Olay çalışması yöntemi kullanılarak yapılan analizin sonucuna göre iyi kurumsal yönetim derecelendirme notunun ilanı ile hisse senedi getirisi arasında pozitif bir ilişkinin olduğu saptanmıştır.

Yenice ve Dölen (2013) tarafından yapılan çalışmada ise, XKURY endeksinde yer alan 37 şirketin 2007-2011 yılları arasında derecelendirme notlarının açıklanma tarihinden 30 gün önce ve 30 gün sonraki borsa değerleri tespit edilmiş ve Wilcoxon İşaretli Sıra Sayılar ve $\mathrm{T}$ testi ile karşılaştırmaları yapılmıştır. Analiz sonucuna göre, derecelendirme notu ile şirketin borsa değeri arasında anlamlı bir ilişkinin varlığ tespit edilmiştir.

Bu çalışmaların yanı sıra kurumsal yönetim uygulamaları ile şirket piyasa değeri arasında ilişki bulamayan veya negatif ilişki bulan çalışmalar da vardır. Örneğin, 2003-2009 yılları arasında BiST bünyesinde işlem gören bankaların kurumsal yönetim derecelendirme notlarının hisse senetlerinin piyasa değerine etkisini Dinçer ve Dinçer (2013) regresyon modeli, t-testi ve ANOVA kullanarak analiz etmiştir. Çalışmanın sonuçlarına göre, kurumsal yönetim derecelendirme notları ile hisse senetlerinin piyasa değeri arasında negatif yönlü bir ilişki tespit edilmiştir. Ege vd. (2013) ise yaptıkları çalışmada 2009-2011 yılları arasında BİST XKURY'de yer alan 18 şirketin derecelendirme notları ile finansal performanslarını TOPSís yöntemiyle incelemişlerdir. Elde edilen sonuçlara göre, kurumsal yönetim derecelendirme notları ile finansal performansların aynı yönde hareket etmediği sonucuna ulaşılmıştır. 
Gupta vd. (2009) yaptıkları çalışmada, 200 Kanadalı şirketin 20022005 yıllarını içeren verileriyle bir uygulama gerçekleştirmişlerdir. Çalışmada kurumsal yönetim derecelendirme notlarının, şirketin piyasa değerine etkisi incelenmiştir. Araştırmanın sonuçlarına göre, kurumsal yönetim derecelendirme notlarının, şirketin piyasa değeri üzerine herhangi bir etkisi gözlenmemiştir.

Bozcuk (2010) ise 2006-2009 yıllarını kapsayan çalışmasında; İMKB Kurumsal Yönetim Endeksi'nde işlem gören şirketlerin derecelendirme notları ile hisse senedi fiyatları arasındaki ilişkiyi incelemiştir. Çok değişkenli regresyon modeli kullanılarak yapılan çalışmanın sonuçlarına göre; kurumsal yönetim derecelendirme notlarının hisse senetlerinin fiyatı üzerine herhangi bir etkisi olmadığ tespit edilmiştir.

Literatür incelendiğinde, özkaynak büyüklüğünün şirketin piyasa değerine etkisi üzerine birbiri ile çelişen sonuçları içeren çalışmaların olduğu görülmektedir. 1982-1992 yılları arasında İtalya'da ilk defa halka arz edilen 139 şirket üzerine yaptıkları çalışmalarında Pagano vd. (1998) özkaynak/toplam aktif oranı ile şirketin piyasa değeri arasında negatif anlamlı bir ilişki tespit etmiştir. Benzer şekilde BİST-100 endeksinde yer alan 63 şirketin 2004-2009 yıllarına ait verileri kullanarak panel veri analizi yaptıkları çalışmalarında Yener ve Karakuş (2012) da özkaynak/aktif oranı ile piyasa değeri arasında anlamlı negatif bir ilişki bulmuştur.

Öte yandan, Barbee vd. (1996) tarafından yapılan çalışmada ise New York Borsası ile Amerika Borsası'na kayıtlı ve finans sektörü dışındaki tüm şirketlerin 1991 yılına kadar 13 yıllık verileri kullanılarak, sermaye yapısının şirketin piyasa değerine olan etkisi incelenmiştir. Regresyon analizi yöntemi kullanılan çalışmanın sonuçlarına göre, özkaynakların toplam aktif içindeki payının artmasının, şirketin piyasa değerini arttırdığı sonucuna ulaşılmıştır. Bayrakdaroğlu (2010) da BíST-100 bünyesinde işlem gören ve bilgilerine ulaşılan 72 şirketin 2005-2009 yıllarına ait verilerini kullanarak yaptıkları çalışmanın sonuçlarına göre, mülkiyet yoğunlaşması ile şirketin piyasa değeri arasında pozitif anlamlı ilişki tespit etmiştir.

Ege ve Bayrakdaroğlu (2008), tarafından yapılan çalışmada ise BíST bünyesinde faaliyette bulunan 6 sigorta şirketinin sermaye yapısı ile piyasa değeri arasındaki ilişki incelenmiştir. Mart 2000-Aralık 2004 dönemleri arasındaki veriler kullanılarak yapılan çoklu regresyon analizinin sonuçlarına göre; sigorta şirketlerinin sermaye yapıları ile piyasa değerleri arasında herhangi bir ilişki tespit edilememiştir. 
Net kârın, şirketlerin piyasa değerlerini arttırıp arttırmadığı son 30 yıldır literatürde yaygınca ele alınan konulardan biridir (Dimitropoulos, 2009:40). Bu çalışmaların birçoğu net kâr ile piyasa değeri arasında pozitif anlamlı ilişkinin varlığını ortaya koymuştur. Örneğin Dimitropoulos (2009) tarafından Atina Borsası'na kayıtlı 105 şirketin 1994-2004 yılları arasındaki verileri kullanılarak yapılan çalışmanın sonuçlarına göre, şirketlerin dönem kârları ile hisse senetleri arasında pozitif yönlü bir ilişki mevcuttur. Benzer ilişkiyi araştıran daha önceki çalışmada Ball ve Brown (1968) 1946-1966 yılları arasında Standard and Poors şirketinin sağlamış olduğu şirket verilerinin tamamını kullanarak dönem kârı ile şirketlerin piyasa değerleri arasında pozitif anlamlı bir ilişkinin varlığını tespit etmişlerdir.

Yabancı literatürde var olan net dönem kârı ve piyasa değeri arasındaki pozitif ilişki Türkiye'de yapılan bazı çalışmalarda da gözlemlenmektedir. Kar vd. (2012) tarafından yapılan çalışmada İMKB bünyesinde işlem gören 4 futbol kulübünün kârlılık durumu ile hisse senetlerinin değeri incelenmiştir. 2005-2010 yılları arası verileri kullanılarak yapılan çalışmaya göre, kârlılık ve kâr dağıtımı ile hisse senetlerinin değeri arasında pozitif anlamlı bir ilişkinin varlığı tespit edilmiştir.

Buna karşılık net dönem kârı ile piyasa değeri arasında herhangi bir ilişki tespit edemeyen çalışmalar da mevcuttur. Demir (2001) 1991 yılında İMKB' de işlem gören ve mali sektörden verilerine ulaşılabilen 16 şirketin 6 aylık verilerini kullandığı çalışmasında dönem net kârı ile şirketlerin piyasa değerleri arasında anlamlı bir ilişki tespit edememiştir.

Mevcut çalı̧̧mada faaliyette bulunan sektörün şirketlerin piyasa değerini etkileyip etkilemediği de araştırılmıştır. Küçükkaplan (2013) şirketlerin piyasa değerinin sektörlere göre farklılık kaydettiği ve bu nedenden dolayı analiz yapılırken sektörel ayrım yapılması gerektiğini belirtmektedir.

\section{Veri Seti, Metodoloji ve Analiz Bulguları}

Çalışmada, hisse senetleri Borsa İstanbul Kurumsal Yönetim Endeksi'nde (BIST XKURY) işlem gören 47 şirketin ulaşılabilen en son verileri olan 2013 yılı üçüncü çeyrek verileri kullanılmıştır. Çalışmaya dâhil edilen şirketlerin listesi aşağıdaki tabloda gösterilmektedir. 
Tablo 1: Analize Dâhil Edilen Şirketlerin Listesi

\begin{tabular}{|l|l|l|}
\hline ANADOLU EFES & COCA COLA & $\begin{array}{l}\text { GLOBAL YATIRIM } \\
\text { HOLDING }\end{array}$ \\
\hline AKBANK & CREDITWEST & $\begin{array}{l}\text { GARANTİ YATIRIM } \\
\text { ORTAKLIĞI }\end{array}$ \\
\hline ALBARAKA & DOĞUŞ OTOMOTIV & HALKBANK \\
\hline ARÇELIK & DOĞAN HOLDING & HURRIYET \\
\hline ASELSAN & $\begin{array}{l}\text { DOĞAN YAYIN } \\
\text { HOLDING }\end{array}$ & IHLAS EV ALETLERİ \\
\hline ASYABANK & EGELİ CO. & IHLAS HOLDİNG \\
\hline AYGAZ & ENKA & İŞ FİNANSAL \\
\hline BOYNER & $\begin{array}{l}\text { GARANTİ } \\
\text { FAKTORING }\end{array}$ & İŞ GAYRIMENKUL \\
\hline İS MENKUL & PINAR SÜT & TSKB \\
\hline LOGO & PRYSMIAN & TÜRK TELEKOM \\
\hline OTOKAR & PARK ELEKTRIK & TÜRK TRAKTÖR \\
\hline PETKIM & ŞEKERBANK & TÜPRAŞ \\
\hline PINAR UN-ET & TAV HAVALIMANI & VESTEL \\
\hline PEGASUS & TOFAŞ & VAKIF MENKUL \\
\hline PINAR SU & TURCAS & YAZICILAR \\
\hline $\begin{array}{l}\text { YEŞİL } \\
\text { GAYRIMENKUL }\end{array}$ & YAPI KREDİ BANKASI & \\
\hline
\end{tabular}

Tablo 1'de görüldüğü üzere, analiz kapsamı olan BIST XKURY'de üretimden finansal sektöre kadar farklı sektörlerde faaliyet gösteren şirketler yer almaktadır.

\section{Modelde Kullanılan Değişkenler}

Çalışmada esas olarak kurumsal yönetim derecelendirme notlarının şirketlerin piyasa değeri üzerine etkisinin araştırılması hedeflenmiştir. Tablo 2'de görüldüğü üzere bağımlı değişken olarak kullanılan şirketin piyasa değeri, toplam hisse senedi sayısı ile birim hisse senedinin piyasa değerinin çarpımı ile bulunmuştur.

Bağımsız değişken olarak kurumsal yönetim derecelendirme notu SPK tarafından yetkilendirilen derecelendirme kuruluşlarının verdikleri 1-10 arasında olan notlar olarak ölçülmüştür. Literatür araştırmasında görüldüğü üzere, regresyon analizi, olay çalışması, Wilcoxon işaretli sıra sayılar testi, T 
testi, TOPSİS gibi yöntemlerin kullanıldığı önceki çalışmaların büyük bir kısmında kurumsal yönetim derecelendirme notu ile şirket değeri arasında pozitif anlamlı ilişki tespit edilmiştir (örneğin; Gomper, 2003; Morey, 2003; Black vd., 2003; Ficici ve Aybar, 2012; Sakarya, 2011; Yenice ve Dölen, 2013). Dolayısıyla, Tablo 2 ' de belirtildiği üzere, yapılacak analizde piyasa değeri ile kurumsal yönetim derecelendirme notu arasında pozitif ilişkinin ortaya çıkması öngörülmektedir.

Özsermaye/aktif oranının piyasa değeri üzerine etkisini ölçen çalışmaların bir kısmında, bu iki değişken arasında anlamlı ve negatif ilişki tespit edilirken (Severin, 2001; Pagano vd., 1998; Yener ve Karakuş, 2012), bir kısmında ise pozitif anlamlı ilişki tespit edilmiştir (Barbee vd., 1996; Bayrakdaroğlu, 2010). Buna karşılık bazı çalışmalarda ise herhangi bir ilişki tespit edilememiştir (Ege ve Bayrakdaroğlu, 2008). Yani önceki çalışma bulguları belirli bir sonuçta yoğunlaşma yerine yaygın sapmalar göstermektedir. Bu nedenle mevcut çalışmada özkaynak/aktif oranı ile şirketin piyasa değeri arasında net bir ilişki beklentisi ifade edilememiştir.

Literatür incelendiği zaman, dönem kârı ile piyasa değeri arasında herhangi bir ilişki bulamayan çalışmalar olmasına rağmen (örneğin; Demir, 2001), çalışmaların önemli bir bölümünde net kâr ile şirketin piyasa değeri arasında pozitif anlamlı sonucun ortaya çıktığı görülmektedir (Dimitropolos, 2009; Ball ve Brown, 1968; Kar vd., 2012). Bu nedenle, yapılacak analizde dönem net kârı ile şirketin piyasa değeri arasında pozitif bir sonucun ortaya çıkması öngörülmektedir.

Son bağımsız değişken olarak da sektörel ayrımın şirketlerin piyasa değerine etkisini ölçmek için kukla değişken kullanılmıştır. Tablo.2'de belirtildiği gibi kurumsal yönetim endeksinde yer alan şirketler finansal ve finansal olmayan sektör olarak ayrıma tabi tutulmuştur. Kullanılan kukla değişkende finansal olmayan sektör şirketleri için " 0 ", finansal sektör şirketleri için "1" kodu kullanılmıştır. BİST Yönetimi'nin 20 Aralık 2013 tarihinde açıkladığı verilere göre (BIST, 2014), BİST bünyesinde işlem gören en değerli şirket sıralamasında ilk on sıra finans sektörü ve finans-dışı sektör arasında eşit olarak paylaşılmaktadır. İlk onda beş adet finansal sektörden (Garanti Bankası, Akbank, İş Bankası, Yapı Kredi Bankası ve Halk Bankası) ve beş adet de finans-dışı sektörden şirket (Turkcell, Koç Holding, Türk Telekom, Enka İnşaat ve Sabancı Holding) yer almaktadır. Bu eşit dağılım dikkate alındığında çalışmada şirketlerin finansal veya finans-dışı sektörlerde yer almasının piyasa değerine nasıl etki yapacağına ilişkin bir öngörüde bulunulamamıştır. 
Tablo 2: Değişkenlerin Açıklanması

\begin{tabular}{|c|c|c|}
\hline Değişken & Açılklama & $\begin{array}{l}\text { Beklenen } \\
\text { Etki }\end{array}$ \\
\hline Piyasa Değeri (PD) & $\begin{array}{l}\text { İşletmenin, hisse senetlerinin piyasa } \\
\text { değeri ile toplam hisse senedi sayısının } \\
\text { çarpımı ile hesaplanmıştır. Analizin } \\
\text { daha uygun yapılması için mutlak } \\
\text { değerin doğal logaritması alınmıştır. }\end{array}$ & \\
\hline $\begin{array}{l}\text { Kurumsal Yönetim } \\
\text { Derecelendirme } \\
\text { Notu (KYDN) }\end{array}$ & $\begin{array}{l}\text { SPK tarafından yetkilendirilen } \\
\text { derecelendirme kuruluşlarının } \\
\text { verdikleri notlardır. 1-10 arasında olan } \\
\text { derecelendirme notu, kurumsal } \\
\text { yönetim endeksinde yer alabilmek için } \\
\text { en az 7 olmalıdır. }\end{array}$ & + \\
\hline $\begin{array}{l}\text { Özsermaye/Aktifler } \\
\text { (Ö/A) }\end{array}$ & $\begin{array}{l}\text { İşletmelerin sahip } \quad \text { olduğu } \\
\text { özkaynakların toplam aktif tutarına } \\
\text { oranlanması ile hesaplanmıştır. Yüzde } \\
\text { olarak ifade edilmiştir. }\end{array}$ & $?$ \\
\hline $\begin{array}{ll}\text { Net Dönem } & \text { Kâr1 } \\
\text { Log. }(\mathrm{NK}) & \end{array}$ & $\begin{array}{l}\text { İşletmelerin elde etmiş oldukları } \\
\text { gelirlerden, vergi ve diğer bütün } \\
\text { giderlerin çıkarılması sonucu elde } \\
\text { edilen tutardır. Analize daha uygun } \\
\text { olabilmesi için mutlak tutarın doğal } \\
\text { logaritması alınmıştır. }\end{array}$ & + \\
\hline $\begin{array}{l}\text { Sektörel } \\
\text { (SA) }\end{array}$ & $\begin{array}{l}\text { Kurumsal Yönetim Endeksi'nde yer } \\
\text { alan şirketler finansal ve finansal } \\
\text { olmayan sektör olarak ayrıma tabi } \\
\text { tutulmuştur. Finansal olmayan sektör } \\
\text { için "0" denilirken, finansal sektör } \\
\text { sirketleri için " } 1 \text { " kodu kullanılmıstır. }\end{array}$ & $?$ \\
\hline
\end{tabular}

Yatay-kesit çoklu regresyon analizinde kullanılacak olan değişkenlerin tanımlayıcı istatistikleri Tablo 3'te gösterildiği gibidir: 
Sosyal Bilimler Dergisi 11

Tablo 3: Tanımlayıcı İstatistikler

\begin{tabular}{|l|c|c|c|c|c|}
\hline & Ort. & Medyan & Max. & Min. & Std. Sapma \\
\hline Piyasa Değeri Log. & 9,03 & 9,17 & 10,47 & 7,06 & 0,85 \\
\hline Derecelendirme Notları & 8,98 & 9,08 & 9,40 & 8,03 & 0,33 \\
\hline Net Dönem Karı Log. & 6,31 & 7,76 & 9,45 & 0,00 & 3,44 \\
\hline Özsermaye /Aktifler \% & 39,62 & 33,16 & 97,91 & 7,90 & 25,73 \\
\hline Sektörel Ayrm & 0,29 & 0,00 & 1,00 & 0,00 & 0,46 \\
\hline
\end{tabular}

Tablo 3'ten de görüleceği üzere analizde yer alan şirketlerin piyasa büyüklüğü logaritmik değer olarak 7,06-10,47 aralığında yer alıp ortalama 9,03 değerine sahiptir. Kurumsal Yönetim Endeksi'nde yer alan 47 şirketin derecelendirme notlarının ortalaması 8,98 iken en yüksek derecelendirme notu 9,40 en düşük not ise 8,03'tür Net dönem kârlarının logaritmik ortalaması 6,31 iken, özsermaye /aktifler değerinin 47 şirket için ortalaması \%39,62'dir. Sektörel ayrımı ölçen kukla değişkenin ortalaması olan 0,29 değeri, endekste yer alan şirketlerin önemli bir bölümünün finans-dışı sektörlerden olduğunu göstermektedir.

\section{Analiz Bulguları}

Regresyon analizinden önce çalışmada yer alan dört adet bağımsız değişken arasında çoklu korelasyon olup olmadığının araştırılması için korelasyon analizi yapılmıştır. Aşağıdaki Tablo 4'de görüldüğü üzere bağımsız değişkenler arasında yüksek korelasyon gözlemlenmemiştir.

Tablo 4: Bağımsız Değişkenler Arasındaki Korelasyon

\begin{tabular}{|l|c|c|c|c|}
\hline & KYDN & NK & Ö/A & SA \\
\hline KYDN & 1,00 & & & \\
\hline NK & 0,26 & 1,00 & & \\
\hline Ö/A & 0,09 & $-0,12$ & 1,00 & \\
\hline SA & 0,004 & 0,22 & $-0,26$ & 1,00 \\
\hline
\end{tabular}

KYND: Kurumsal Yönetim Derecelendirme Notu, NK: Net Dönem Kârl,

Ö/A: Özsermaye /Aktifler (\%), SA: Sektörel Ayrrm

Çoklu korelasyon sorununun olmadığına işaret eden korelasyon analizini takiben regresyon analizi gerçekleştirilmiştir. En küçük kareler yatay-kesit çoklu-regresyon analizinin sonuçları Tablo 5 'te verilmiştir. 
Tablo 5: Regresyon Analizi Sonuçları

\begin{tabular}{|l|c|c|c|c|}
\hline $\begin{array}{l}\text { Bağımlı Değişken: PIYASA DEGERI } \\
\text { Yöntem: En Küçük Kareler } \\
\text { Dâhil edilen gözlem sayısı: } 47\end{array}$ \\
\hline \multicolumn{1}{|c|}{ DEĞİSEN } & Katsayı & Std. Hata & t-istatistiği & Olasıllk \\
\hline \multicolumn{1}{|c|}{ C } & 4.1695 & 2.4261 & 1.7185 & 0.0931 \\
\hline $\begin{array}{l}\text { Kurumsal Yönetim } \\
\text { Derecelendirme Notu }\end{array}$ & 0.5317 & 0.2758 & 1.9276 & 0.0607 \\
\hline Net Dönem Kârı Log. & 0.1301 & 0.0277 & 4.6850 & 0.0000 \\
\hline Özsermaye /Aktifler (\%) & -1.3932 & 0.3636 & -3.8310 & 0.0004 \\
\hline Sektörel Ayrım & -0.6208 & 0.2046 & -3.0341 & 0.0041 \\
\hline R-squared & 0.547166 & Mean dependent var & 9.032326 \\
Adjusted R-squared & 0.504039 & S.D. dependent var & 0.859375 \\
S.E. of regression & 0.605211 & Akaike info criterion & 1.933808 \\
Sum squared resid & 15.38376 & Schwarz criterion & 2.130632 \\
Log likelihood & -40.44448 & Hannan-Quinn criter. & 2.007874 \\
F-statistic & 12.68732 & Durbin-Watson stat & 2.208878 \\
Prob(F-statistic) & 0.000001 & \\
\hline
\end{tabular}

Tablo 5'de yer alan sonuçlara göre BİST XKURY'de yer alan şirketlerin derecelendirme notlarının, piyasa değeri üzerine pozitif anlamlı yönde bir etkisi vardır ( $t$ değeri 1,$92 ; p<0,10$ ). Benzer şekilde piyasa değeri ile net dönem kârı ( $t$ değeri 4,68; $p<0,00$ ) arasında da pozitif anlamlı ilişki vardır. Regresyon analizi bulgularına göre finans-dışı sektör şirketleri finansal şirketlere göre daha büyük piyasa değerine sahiptir (t değeri -3,03; $\mathrm{p}<0,00)$. Çalışmada piyasa değeri ile özsermaye büyüklüğü arasında ise istatistiksel olarak anlamlı negatif ilişki bulunmuştur (t değeri $-3,83 ; p<0,00$ ).

\section{Sonuç}

1990'l1 yıllardan itibaren yaşanan ve küresel çapta etkisini gösteren finansal skandalların ardından kurumsal yönetim ilkelerinin belirlenip uygulanmasına global ölçekte büyük önem arz etmeye başlanmıştır. Türkiye de kurumsal yönetim ilkelerine yönelik düzenlemeler çerçevesinde 1999 yılında TBB, 2002 yılında TÜSİAD ve 2003 yılında SPK tarafından yayımlanan çalışmalarla ilk gerekli adımları atmıştır. 2007 yılında da borsa bünyesinde kurumsal yönetim endeksi faaliyete başlamıştır. Kurumsal yönetim derecelendirme notu en az 7 olan şirket sayısının 5’e ulaşması ile BİST bünyesinde hesaplanmaya başlayan endekste, 2014 yılı şubat ayı itibari 
ile yeterli kurumsal derecelendirme notuna sahip olan 47 şirket bulunmaktadır.

Çalışmada BİST XKURY'e kote olan 47 şirketin 2013 yılı 3. çeyrek sonu verileri kullanılarak kurumsal yönetim derecelendirme notunun şirketlerin piyasa değerlerine olan etkisi araştırılması hedeflenmiştir. Analizde kurumsal yönetim derecelendirme notları yanı sıra bağımsız değişken olarak kârlılık, özsermaye büyüklüğü ve sektörel ayrım da dâhil edilmiştir. Verilerin analizi için en küçük kareler yöntemine dayalı yataykesit çoklu regresyon analizi kullanılmıştır.

Analiz sonucu piyasa değeri ile kurumsal yönetim derecelendirme notları arasında pozitif anlamlı bir ilişki tespit edilmiştir. Bu sonuca göre, kurumsal yönetim derecelendirme notları yüksek olan şirketlerin, piyasa değeri de yüksek olmaktadır. Bu sonuç; Gomper vd., (2003); Morey, (2003); Black vd., (2003); Ficici ve Aybar, (2012); Yenice ve Dölen, (2013) ve Sakarya'nın, (2011) çalışmalarında elde ettiği sonuçlar ile paralellik göstermektedir.

Piyasa değerine istatistiksel olarak anlamlı düzeyde pozitif yönde etki eden bir diğer değişken net dönem kârıdır. Bu sonuç da literatürdeki çalışma bulgularını teyit etmektedir (Dimitropolos, 2009; Ball ve Brown, 1968; Kar vd., 2012).

Analiz bulguları sektörel ayrımın şirketlerin piyasa değerini etkilediğini ortaya koymaktadır. Her ne kadar BIST bünyesindeki en değerli şirket sıralamasında ilk onu eşit sayıda şirket ile paylaşmış olsalar da çalışma sonuçlarına göre finans sektöründeki şirketlere göre finans-dışı sektör şirketleri daha büyük seviyede piyasa değerine sahiptirler. Finans sektörünün şirket değeri açısından dezavantajlı konumu bu bankaların son dönemlerde gözlemlenen kırılgan yapısından kaynaklanabilir. Laeven and Valencia (2012) tarafından belirtildiği üzere, 1997'de başlayan global kriz, Büyük Buhrandan sonra en büyük banka krizlerine neden olmuştur. Yakın bir tarih olan 2009'da Danimarka, Yunanistan, Almanya'da, 2010'da Kazakistan'da ve 2011 'de İspanya'da yapısal boyuta ulaşan banka krizleri yatırımcıları tedirgin eden faktör olarak değerlendirilebilir.

Analiz sonuçlarına göre, özsermaye/aktifler oranının piyasa değeri üzerine istatistiksel olarak anlamlı düzeyde negatif etkisinin olduğu bulunmuş olup bu sonuç literatürdeki bazı çalışmalarla (Severin, 2001; Pagano vd., 1998; Yener ve Karakuş, 2012) paralellik göstermektedir. Aktiflerin yoğun bir şekilde özkaynaklar ile finanse edilmesi öncelikle Kıta Avrupası'nda bir fonlama yöntemi olup Anglo-Saxon kurumsal yönetim biçimine aykırılık göstermektedir. Yoğunlaşmış hisse payları ile mevcut hâkim hissedarlar kendilerine stratejik kararlarda çok büyük yetki imkânı 
sağladığı için potansiyel yatırımcılar bu tür şirketlere karşı mesafe sergileyebilmektedirler. Dolayısıyla şirketler, özsermaye hacmini optimal bir düzeyde tutarak piyasa değerinin düşmesine engel olmalıdırlar.

Sonuç olarak, 2003 yılında SPK tarafından şirketlere uygulama deneyimi başlanan kurumsal yönetim uygulamaları gelişimini hala devam ettirmektedir. Kurumsal yönetimin ülkemizde uygulanabilirliğinin yeterli düzeyde olmadığ ${ }_{1}$ Kurumsal Yönetim Endeksi'nde sadece 47 şirketin olması ile ortaya çıkmaktadır. Borsada işlem gören şirket sayısının 430 olduğu düşünüldüğünde 47 şirket yetersiz bir büyüklüğü temsil etmektedir. Şirketlerin kurumsal yönetim ilke ve uygulamalarına gerekli önemi vermeleri yatırımcıların getiri elde etmelerinin bir tür göstergesi olacak ve şirketlerin de etkin bir şekilde fon temin etmelerinin önünü açabilecektir.

\section{Kaynakça}

Acar, M., Temiz, H. ve Karan, M. B., (2013), BİST(Borsa İstanbul) Kurumsal Yönetim Endeksinde (XKURY) Yer Alan Şirketlerin Getiri ve Performans Analizi: Olay Çalışması Örneği, 17.Finans Sempozyumu 23-26 Ekim 2013/Muğla: ss. 130 - 142.

Aktan, C. C. (2006). Kurumsal Şirket Yönetimi. Sermaye Piyasası Kurulu Kurumsal Araştırmalar Serisi Ankara: Onuray Reklamcılık ve Matbaacilık, ss. 1-34

Aysan, M. A. (2007). Muhasebe ve Kurumsal Yönetim. Muhasebe ve Finansman Dergisi- MUFAD Journal, Issue 35, ss. 17-24.

Ball, R., and Brown, P. (1968), An Empirical Evaluation of Accounting Income Numbers, Journal of Accounting Research, Autumn, ss. 159 178.

Barbee W. C., Mukherjı. S. and Raines G.A. (1996), Do Sales Price and Debt Equity Explain Stock Returns Better than Book-Market and Firm Size?", Financial Analysts Journal, 52(2), ss. 56-60.

Bayrakdaroğlu, A. (2010), Mülkiyet Yapısı ve Finansal Performans: İMKB Örneği, Ekonomi Bilimleri Dergisi, 2(2), ss. 11-20.

BİST, 2013. Kurumsal Yönetim Endeksi. [Çevrimiçi]:http://www.imkb.gov.tr/indexes/stockindexeshome/Cor porateGovernanceIndex.aspx [18 Aralık 2013 tarihinde erişilmiştir].

BİST, 2014. Borsa İstanbul Hisse Senetleri Piyasası Verileri. [Çevrimiçi]: http://borsaistanbul.com/veriler/verileralt/hisse-senetleri-piyasasiverileri/sirketler-verileri [03 Mart 2014 tarihinde erişilmiştir]. 
Black, Jang and Kim (2003), “Does Corporate Governance Affect Firms' Market Values?, Social Science Research Network electronic library at: http://papers.ssrn.com/abstract $=311275$.

Bozcuk, A. (2010). Price Reaction to Corporate Governance Ratıng Announcements at the Istanbul Stock Exchange. International Journal of Economics and Finance Studies, 2(1), ss.1-6.

Demir, Y. (2001), Hisse Senedi Fiyatını Etkileyen İşletme Düzeyindeki Faktörler ve Mali Sektör Üzerine İMKB'de Bir Uygulama, Süleyman Demirel Üniversitesi İktisadi ve İdari Bilimler Fakültesi, 6(2), ss.109-130.

Dimitropoulos, P. E. (2009), The Relationship between Earnings and Stock Returns: Empirical Evidence from the Greek Capital Market, International Journal of Economics and Finance, 1(1), ss.40-50.

Dinçer, B. ve Dinçer. C. (2013). Corporate Governance and Market Value: Evidence from Turkish Banks. International Journal of Academic Research in Business and Social Sciences, 3(1), ss.241-249.

Ege, İ. ve Bayrakdaroğlu, A. (2008), Sermaye Yapısının Cari Değer ve Verimlilik Üzerine Etkisi: Türk Sigortacılık Sektöründe Bir Uygulama, Atatürk üniversitesi İktisadi ve İdari Bilimler Dergisi, 22 (2), ss.379-395.

Ege, İ., Topaloğlu E. E. ve Özyamanoğlu M., (2013), Finansal Performans İle Kurumsal Yönetim Notları Arasındaki İlişki: BİST Üzerine Bir Uygulama, Akademik Araştırmalar ve Çalışmalar Dergisi 5(9), ss. 100 117.

Ficici, A. and Aybar, C.B. (2012). Corporate Governance and Firm Value in Emerging Markets An Empirical Analysıs of ADR Issuing Emerging Market Firms. Emerging Markets Journal, 2(2012), ss.37-51.

Gompers, P., Ishı1, J. \& Metrick, A., (2003). Corporate Governance And Equity Prices. Quarterly Journal of Economics, 118(1), pp. 107-155

Gupta, P.,P., Kennedy, D., B. and Weaver, S.C. (2009), Corporate Governance and Firm Value: Evidence from Canadian Capital Markets, Corporate Ownership \& Control , 6(3), ss. 293-307.

Güçlü, H., (2010). Kurumsal Yönetim Uyum Derecelendirmesi. İstanbul: Ufuk Reklamcılık Matbaacılık

Kar, A., Özer, Ö., Şantaş, F. ve Budak, F. (2012), Kâr Dağıtımının Hisse Senedi Değeriyle İlişkisi: Spor Hizmetleri Sektörü Üzerine Bir Uygulama, Ekonomi Bilimleri Dergisi, 4(1), ss.1-9.

Küçükkaplan, İ. (2013), İstanbul Menkul Kıymetler Borsasında İşlem Gören Üretim Firmalarının Piyasa Değerini Açılayan İçsel Değişkenler: Panel Verilerle Sektörel Bir Analiz, Eskişehir Osmangazi Üniversitesi İ̈BF Dergisi, Ekim 2013, 8(2), ss.161-182 
Laeven, L. \& Valencia, F. (2012), "Systemic Banking Crises Database: An Update", IMF Working Paper, WP/12/163.

McKinsey Company 2002, Global Investor Opinion Survey on Corporate Governance, Key Findings, http://ww1.mckinsey.com/clientservice/organizationleadership/servi ce/corpgovernance/PDF/GlobalInvestorOpinionSurvey2002.pdf, Erişim Tarihi: 13.02.2014

Morey M., Gottesman A., Baker E. And Godridge B. (2009) “Does better corporate governance result in higher valuations in emerging markets? Another examination using a new data set", Journal of Banking and Finance, Volume 33, pp. 254-262.

OECD (2004), Principles of Corporate Governance, www.oecd.org

Pagano M., Panetta F. ve Zingales L. (1998). Why Do Companies Go Public? An Empirical Analysis, The Journal of Finance, 53(1),ss. 27-64.

Sakarya, Ş. (2011). İMKB Kurumsal Yönetim Endeksi Kapsamındaki Şirketlerin Kurumsal Yönetim Derecelendirme Notu ve Hisse Senedi Getirileri Arasındaki İlişkinin Olay Çalışması Yöntemi ile Analizi. ZKÜ Sosyal Bilimler Dergisi, 7(13), ss.147-162.

Sermaye Piyasası Kurulu Kurumsal Yönetim İlkeleri, Temmuz 2003, s.5

Severin, E. (2001), Ownership structure and the performance of firms: Evidence from France, European Journal of Economic and Social Systems, 15(2), ss. 85-107.

Sherman, H., (2004). Corporate Governance Rating. Corporate Governance: An International Review, 12(1), pp. 5-7

Shleifer, A., ve Vishny. R.W., (1997). A Survey of Corporate Governance. The Journal of Finance, Issue 52(2), pp 737-783

TBB, (1999).Türkiye Bankalar Birliği Bankacılık ve Araştırma Grubu, Basel Bankacılık Gözetim Komitesi, 1999. Bankalarda Kurumsal Yönetim. [Çevrimiçi]

http://www.google.com.tr/url?sa=t\&rct=j\&q=\&esrc=s\&source=web\& $\mathrm{cd}=1 \&$ ved=0CDEQFjAA\&url=http $\% 3 \mathrm{~A} \% 2 \mathrm{~F} \% 2 \mathrm{Fwww} \cdot \mathrm{tbb}$. org.tr\%2F Dosyalar\%2FArastirma_ve_Raporlar\%2F2kurumsal.doc\&ei=ilcaUbf BHcn34QSwvYHYBQ\&usg=AFQjCNHgPbz7jZI9opoeF32JKLrZz47Jl A\&bvm=bv.42261806,d.bGE [12 Şubat 2013 tarihinde erişilmiştir]

TKYD,(Eylül 2011). Ekonomi Gazeteciliği İçin Kurumsal Yönetim El Kitabı. İstanbul: Pasifik Ofset

TÜSİAD (2002), Kurumsal Yönetim En iyi Uygulama Kodu: Yönetim Kurulunun Yapısı ve İşleyişi, TS/ŞíR/02-192/2002, http://www.tusiad.org/02.htm 
Sosyal Bilimler Dergisi 17

Yener, E. ve Karakuş, R. (2012), Sermaye Yapısı ve Firma Değeri İliş̧kisinin Farklı Aktif Büyüklüklerde Karşılaştırmalı İncelenmesi: IMKB 100 Firmaları Üzerine Bir Uygulama, Gazi Üniversitesi İktisadi ve İdari Bilimler Fakültesi Dergisi, 14(2), ss.75-88.

Yenice, S. ve Dölen, T., (2013). İMKB'de İşlem Gören Firmaların Kurumsal Yönetim İlkelerine Uyumunun Firma Değeri Üzerine Etkisi. Uluslararası Yönetim İktisat ve İşletme Dergisi, 9(19), ss. 199-214. 